\title{
STUDI TINGKAT PENGETAHUAN IBU YANG BEKERJA TENTANG PERKEMBANGAN SOSIAL ANAK PRASEKOLAH DI DESA SIMOGIRANG KECAMATAN PRAMBON, SIDOARJO
}

\author{
Agus Sulistyowati ${ }^{1}$, Ratna Kisdiarti \\ ${ }^{1}$ Akademi Keperawatan Kerta Cendekia Sidoarjo \\ Corresponding: agus_sulistyowati78@yahoo.com
}

\begin{abstract}
Abstrak
Introduction. Perkembangan sosial merupakan proses belajar untuk menyesuaikan diri terhadap norma-norma kelompok, moral dan tradisi; meleburkan diri menjadi satu kesatuan dan saling berkomunikasi dan kerja sama (Yusuf, 2007). Studi pendahuluan tentang tingkat pengetahuan dari 10 ibu bekerja dan mempunyai anak prasekolah di Desa Simogirang Kecamatan Prambon Sidoarjo, 2 mempunyai tingkat pengetahuan baik, 3 mempunyai tingkat pengetahuan cukup, 5 mempunyai tingkat pengetahuan kurang. Tujuan penelitian ini adalah untuk mengetahui tingkat pengetahuan ibu yang bekerja tentang perkembangan sosial anak prasekolah. Methods. Metode penelitian yang digunakan adalah deskriptif. Sampel yang digunakan sebanyak 44 orang. Teknik sampling yang digunakan adalah total sampling. Teknik pengumpulan data menggunakan kuisoner dengan jumlah pertanyaan 20 soal. Setelah data terkumpul dilakukan tabulasi dalam bentuk tabel distribusi frekuensi, data diinterprestasikan sehingga menghasilkan suatu simpulan. Results. Hasil penelitian menunjukkan bahwa responden dengan tingkat pengetahuan baik sebanyak 6 responden (14\%), tingkat pengetahuan cukup sebanyak 12 responden (27\%) dan tingkat pengetahuan kurang sebanyak 26 responden (59\%). Discussion. Dari hasil penelitian tersebut disimpulkan bahwa tingkat pengetahuan ibu yang bekerja tentang perkrmbangan sosial anak prasekolah kurang, maka perlu ditingkatkan pengetahuan ibu dengan pemberian penyuluhan oleh petugas kesehatan.
\end{abstract}

Keywords: Tingkat Pengetahuan, Perkembangan Sosial

\section{Pendahuluan}

Perkembangan sosial merupakan pencapaian kematangan dalam hubungan sosial (Yusuf, 2007). Pada awal manusia dilahirkan belum bersifat sosial, dalam artian belum memiliki kemampuan dalam berinteraksi dengan orang lain. Kemampuan sosial anak diperoleh dari berbagai kesempatan dan pengalaman bergaul dengan orang-orang di lingkungannya. Kebutuhan berinteraksi dengan orang lain telah dirasakan sejak usia enam bulan, di saat itu mereka telah mampu mengenal manusia lain, terutama ibu dan anggota keluarganya. Anak mulai mampu membedakan arti senyum dan perilaku sosial lain, seperti marah (tidak senang mendengar suara keras) dan kasih sayang. Kehadiran orang tua terutama ibu sangat berpengaruh bagi anak karena ibu sebagai guru pertama untuk seorang anak, namun kenyataannya di jaman modern ini lebih banyak ibu yang menjadi wanita karir. Karena kesibukan tersebut para ibu biasanya kurang mengetahui dan mendapatkan informasi tentang sesuatu yang baru (Glik, 2004). Kejadian di Desa Simogirang Kecamatan Prambon Kabupaten Sidoarjo yaitu karena kesibukan pekerjaan, ibu kurang mengetahui informasi tentang perkembangan sosial anak yang baik atau sesuai dengan umurnya. hal tersebut dibuktikan dengan banyaknya anak bermain dengan orang dewasa atau anak remaja yang mempunyai perilaku maupun sikap yang kurang baik sehingga sering kali meniru perilaku dan gaya bahasa yang digunakan orang dewasa seperti bermain kartu, berkata keras dan membentak terhadap orang yang lebih tua, tidak mau mendengarkan nasihat yang diberikan orang lain, banyak ibu bekerja yang berpendapat bahwa sikap atau peilaku anak tersebut merupakan hal wajar yang terjadi pada anak seusianya.

Perkembangan kehidupan sosio-kultural menuntut wanita untuk ikut aktif mengembangkan karir sesuai dengan minat dan latar belakang pendidikan selain sebagai ibu rumah tangga. Banyak kaum ibu yang bekerja karena tuntutan ekonomi keluarga. Menurut Nursalam (2008) menjelaskan bahwa pekerjaan umumnya merupakan hal yang penting dan cenderung menyita waktu, semakin giat/sibuk seseorang bekerja semakin besar kemungkinan mengabaikan informasi yang didapat sehingga semakin sedikit pengetahuan yang dimiliki. Hal tersebut memungkinkan ibu untuk tidak mengetahui informasi-informasi tentang perkembangan sosial anak. Pengetahuan akan mempengaruhi sejauh mana ibu dalam memantau dan mengarahkan perkembangan sosial anak yang sesuai. Sebagai akibat dari kurangnya pengetahuan, ibu akan membiarkan anak mereka mempunyai perkembangan sosial yang kurang baik. Menurut penelitian yang dilakukan oleh Soekerman (1985) dalam Glick (2004), kondisi ini dapat memberikan dampak secara langsung maupun tidak langsung terhadap perkembangan sosial anak. dampak secara langsung dapat berupa keterlambatan perkembangan sosial seperti: anak menjadi penakut, pendiam, pemalu, sulit berinteraksi 
dengan teman atau orang lain. Atau menunjukkan kemajuan perkembangan sosial yang buruk karena biasanya anak lebih suka bergaul dengan remaja yang mempunyai perilaku yang kurang baik, seperti: menggunakan bahasa yang tidak sopan, perilaku kasar dan dapat juga memberi dampak secara tidak langsung dimasa depan anak berupa resiko kenakalan remaja.

Melihat banyaknya ibu yang belum mengenal tentang perkembangan sosial anak, maka upaya yang dilakukan adalah bekerjasama dengan petugas kesehatan setempat untuk memberikan penyuluhan dan pengarahan tentang perkembangan sosial anak dengan tujuan ibu dapat menerapkan ilmu yang didapat dalam menilai perkembangan sosial anak maupun memberikan ilmunya kepada orang terdekat (kakek, nenek saudara), menyarankan kepada ibu untuk mengunakan pengasuh pengganti yang terlatih selama orang tua bekerja, dan lebih sering berinteraksi kepada anak dengan melakukan Tanya jawab. Berdasarkan fenomena diatas mendorong peneliti untuk mempelajari tingkat pengetahuan ibu yang bekerja tentang perkembangan sosial anak prasekolah.

\section{Metode dan Bahan}

Metode dalam penelitian ini menggunakan metode penelitian deskriptif, yaitu metode penelitian yang bersifat mendeskripsikan (memaparkan) peristiwa-peristiwa target yang terjadi pada masa kini. Penelitian ini dilakukan pada November 2016 di Desa Simogirang Kecamatan Prambon Kabupaten Sidoarjo. Populasi dalam penelitian ini adalah semua ibu bekerja yang mempunyai anak prasekolah di Desa simogirang Kecamatan Prambon Kabupaten Sidoarjo sebanyak 44 ibu. Teknik sampling yang digunakan dalam penelitian ini adalah total sampling, sehingga seluruh populasi penelitian dijadikan sebagai responden pada penelitian ini. Instrumen yang digunakan dalam penelitian ini adalah kuesioner. Dalam proses pengumpulan data pada penelitian ini. Pertama peneliti meminta izin ke Kepala desa setempat dengan membawa surat izin dari institusi, untuk meminta data tentang jumlah ibu bekerja yang mempunyai anak prasekolah dengan cara datang kesetiap sekolah taman kanak-kanak dan ketua RW di Desa Simogirang Kecamatan Prambon Kabupaten Sidoarjo untuk mencari anak prasekolah yang mempunyai ibu bekerja, data tersebut digunakan untuk membuat karya tulis ilmia. Setelah memperoleh izin dan data dari Kepala desa, seterusnya peneliti membuat proposal yang akan diajukan ke Institusi. Sebelum melakukan penelitian di lapangan peneliti memberikan surat ijin penelitian dari Institusi yang diberikan kepada Kepala desa. Setelah memperoleh ijin dari Kepala desa untuk melakukan penelitian di Desa Simogirang Kecamatan Prambon Kabupaten Sidoarjo, kemudian peneliti melakukan penelitiannya dengan cara mengumpulkan data dengan cara memberikan kuesioner yang berupa daftar pertanyaan yang berupa formulir-formulir yang diajukan secara tertulis kepada sejumlah responden untuk mendapatkan tanggapan, informasi dan jawaban. Setelah data terkumpul di lakukan editing, coding, scoring dan tabulating.

\section{Hasil Penelitian}

Berdasarkan dari hasil pengumpulan data diketahui bahwa sebagian responden memiliki tingkat pengetahuan baik sebanyak 6 responden (14\%), memiliki tingkat pengetahuan cukup sebanyak 12 responden $(27 \%)$ dan memiliki tingkat pengetahuan kurang sebanyak 26 responden (59\%).

\section{Pembahasan}

Berdasarkan hasil penelitian yang dilakukan pada November 2016 menunjukkan bahwa studi tingkat pengetahuan Ibu yang bekerja tentang perkembangan sosial anak prasekolah di Desa Simogirang Kecamatan Prambon Kebupaten Sidoarjo lebih dari setengahnya mempunyai tingkat pengetahuan kurang dengan jumlah 26 responden $(59 \%)$. Kurangnya pengetahuan responden tersebut kemungkinan dipengaruhi oleh beberapa faktor, di antaranya usia, pendidikan, pekerjaan, jumlah anak, sumber informasi, dan pernah tidaknya memperoleh informasi.

Usia erat kaitannya dengan tingkat pengetahuan seseorang. Seharusnya semakin dewasa umur seseorang, maka semakin baik pula tingkat pengetahuan. Karena dengan bertambahnya umur, maka bertambah pula ilmu serta informasi yang didapat baik dari luar maupun dari dalam sehingga ilmu dan informasi tersebut dapat menambah pengetahuan seseorang. Menurut Erfandi (2009) Usia mempengaruhi terhadap daya tangkap dan pola pikir seseorang. Semakin bertambah usia akan semakin berkembang pula daya tangkap dan pola pikirnya, sehingga pengetahuan yang diperolehnya semakin membaik. Sedangkan menurut Harlock (2004), usia adalah umur individu yang terhitung mulai saat dilahirkan sampai saat berulang tahun. Semakin cukup umur, tingkat kematangan dan kekuatan seseorang akan lebih matang dalam berpikir dan bekerja.

Pendidikan berarti bimbingan yang diberikan oleh seseorang terhadap perkembangan orang lain menuju ke arah suatu cita - cita tertentu. Makin tinggi tingkat pendidikan seseorang, makin mudah menerima informasi sehingga makin banyak pula pengetahuan yang dimiliki. Menurut Erfandi (2009) Pendidikan adalah suatu usaha untuk mengembangkan kepribadian dan kemampuan di dalam dan di luar sekolah dan berlangsung seumur hidup. Pendidikan mempengaruhi proses belajar, makin tinggi pendidikan seeorang makin mudah orang tersebut untuk menerima informasi. Dengan pendidikan tinggi maka seseorang akan cenderung untuk mendapatkan informasi. Semakin banyak informasi yang diperoleh baik dari pendidikan formal maupun non-formal dapat memberikan pengaruh 
jangka pendek (immediate impact) sehingga menghasilkan perubahan atau peningkatan pengetahuan. Sebaliknya pendidikan yang kurang akan menghambat perkembangan sikap seseorang terhadap nilai - nilai yang baru diperkenalkan.

Tingkat pengetahuan kurang berdasarkan pekerjaan adalah ibu bekerja yang mempunyai pekerjaan swasta (buruh pabrik) dibandingkan dengan pegawai negeri sipil yang tidak terdapat tingkat pengetahuan yang kurang. peneliti berpendapat dimana PNS sebagai pegawai pemerintahan yang dituntut untuk selalu memperbaruhi informasi, jangkauan informasi yang mudah dicapai dengan cara mengikuti seminar ataupun pelatihan. Hal tersebut berbeda dengan pegawai swasta (buruh pabrik) dan PRT yang pekerjaanya terfokus pada satu pekerjaan sehingga untuk memperoleh informasi lebih sedikit dari pada PNS. Dengan kesibukan dalam pekerjaan, seseorang dapat mengacuhkan sagala informasi disekitarnya dengan demikian informasi sulit untuk diperoleh. UU Nomor 43 Tahun 1999 menyatakan pegawai negeri sipil dalam jabatan fungsional berorientasi pada prestasi kerja, sehingga tujuan untuk mewujudkan pegawai negeri sipil sebagai aparatur negara yang berdaya guna dan berhasil guna dalam melaksanakan tugas umum pemerintahan dan pembangunan dapat dicapai. Terkadang pekerja serta kesibukannya dapat menjadikan seseorang langsung maupun tidak langsung menjadi individu yang kurang memperhatikan sesuatu disekitar, hal ini dipengaruhi banyak faktor diantaranya kondisi tubuh ketika orang seharian bekerja.

Jumlah anak berpengaruh pada pengalaman ibu, semakin banyak pengalaman yang dimiliki maka semakin banyak pengetahuan ibu. Menurut Notoatmodjo (2007) jumlah anak berkaitan dengan adanya pengalaman ibu, pengalaman sebagai sumber pengetahuan adalah suatu cara untuk memperoleh kebenaran pengetahuan yang diperoleh dalam memecahkan masalah yang dihadapi masa lalu.

Informasi sangat mempengaruhi pengetahuan, karena dengan memperoleh banyak informasi maka seseorang akan lebih mengerti dan faham. Ibu bekerja harus mengetahui terlebih dahulu tentang perkembangan sosial anak prasekolah, setelah tahu ibu akan dapat mengaplikasikannya. Selain itu seseorang akan tambah banyak pengetahuan dan bisa menyikapi pada kondisi yang terjadi pada diri orang itu sendiri. Menurut Syaifudin (2007) Informasi adalah keseluruhan makna, dapat diartikan sebagai pemberitahuan seseorang. Adanya informasi baru mengenai suatu hal memberikan landasan kognitif baru terbentuknya sikap terhadap hal tersebut. Pesan-pesan sugestif dibawa oleh informasi tersebut, apabila cukup akan memberi dasar efektif dalam menilai suatu hal sehingga terbentuknya arah sikap tertentu.

Ibu bekerja yang sudah mendapatkan informasi dari tetangga mempunyai pengetahuan yang kurang, hal ini disebabkan informasi dari tetangga kurang bisa dipertanggungjawabkan kebenarannya, karena informasi diperoleh dari mulut ke mulut yang bersifat subyektif, informasi yang disampaikan dapat berubah dari kebenarannya . Berbeda dengan cara memperoleh informasi dari petugas kesehatan yang tentunya bisa dipertanggungjawabkan kebenarannya karena bersumber dari para ahli yang kemungkinan kecil berubah dari kebenarnya. Menurut Notoatmojo (2003) informasi akan memberikan pengaruh pada pengetahuan seseorang meskipun seseorang mempunyai pendidikan yang rendah, tetapi jika seseorang mendapatkan informasi langsung dari petugas kesehatan maka akan lebih bisa memahami dan lebih aktif bertanya, hal ini akan dapat meningkatkan pengetahuan seseorang. Menurut Effendy (2004) menyatakan penyuluhan kesehatan adalah kegiatan pendidikan yang dilakukan dengan cara menyebarkan pesan, menanamkan keyakinan, sehingga masyarakat tidak saja sadar, tahu dan mengerti, tetapi juga mau dan bisa melakukan suatu anjuran yang ada hubungannya dengan kesehatan. Seseorang akan lebih mengetahui dan memahami secara benar tentang suatu informasi dan mau melakukan sesuatu yang disarankan apabila bertatap muka secara langsung dengan petugas yang dianggap sebagai contoh yang dipertanggungjawabkan kebenaranya.

\section{Simpulan}

Berdasarkan hasil penelitian dapat disimpulkan bahwa tingkat pengetahuan Ibu yang bekerja tentang perkembangan sosial anak prasekolah di Desa Simogirang Kecamatan Prambon Kebupaten Sidoarjo lebih dari setengahnya mempunyai tingkat pengetahuan kurang sebanyak 26 responden (59\%).

\section{Saran}

Untuk lebih peduli dan meningkatkan pangetahuan tentang perkembangan sosial anak, diharapkan para ibu bekerja lebih aktif dan lebih banyak informasi yang dapat menambah pengetahuan. Hal ini dapat dilakukan dengan cara membaca leaflet-leaflet atau informasi melalui media cetak, media elektronik, petugas kesehatan dan menyempatkan untuk ikut penyuluhan tentang perkembangan sosial anak. Diharapkan kader-kader kesehatan atau puskesmas di Desa Simogirang Kecamatan Prambon Kebupaten Sidoarjo memberikan informasi dan penyuluhan pada ibu bekerja yang mempunyai anak prasekolah tentang perkembangan sosial anak sehingga pengetahuan ibu bekerja bertambah dan terbentuk pengetahuan yang baik, dengan demikian ibu bekerja dapat mengetahui apabila terjadi penyimpangan pada perkembangan sosial anak prasekolah. Diharapkan untuk peneliti selanjutnya Sampel ditetapkan lebih banyak karena akan mempengaruhi hasil penelitian. Penelitian dapat dilakukan di daerah lain yang respondenya lebih bayak, 
sehingga dapat diketahui bagaimana pengetahuan para ibu bekerja tentang perkembangan sosial anak prasekolah di daerah lain.

\section{Daftar Pustaka}

Arikunto, Suharsini. (2006). Prosedur Penelitian Suatu Pendekatan Praktek. Jakarta: Rineka Cipta.

Azwar, Saifuddin. (2009). Sikap Manusia Teori Dan Pengukuranya. Yogyakarta: Pustaka Pelajar

Davidson G. dkk. (2006). Psikologi Abnormal. Jakarta: PT Raja Grafindo Persada.

Erfandi. (2009). Konsep pengetahuan.

Gunarsa, Singgih. (2004). Psikologi Perkembangan Anak, Remaja dan Keluarga. Jakarta: PT. Gunung Mulia.

Harlimsyah. (2007). Perkembangan Sosial Anak. http://digilib.unimus.ac.id/files/disk 1 104/septianawi-5158-3-bab2.pdf.

Hidayat, Aziz Alimul. (2004). Riset Keperawatan dan Teknik Penulisan Ilmiah. Jakarta: Salemba Medika.

Hildayani, Rini. (2013). Psikologi Perkembangan Anak. Jakarta: Universitas Terbuka.

Hurlock, Elizabeth B. (2004). Perkembangan Anak. Jakarta: Erlangga.

Hurlock, Elizabeth B. (2011). Perkembangan Anak Jilid 1. Jakarta: Erlangga.

L e r n e r. ( ( $\left.\begin{array}{llll}2 & 0 & 0 & 4\end{array}\right)$. I $b u$ B e ker $j a$. http://repository.usu.ac.id/bitstream/123456789 /32433/4/20II.pdf.

Melntosh dan Bauer. (2006). Ibu Bekerja. http://repository.usu.ac.id/bitstream/ 123456789/32433/4/20II.pdf.

Notoatmodjo, Soekidjo. (2003). Metodologi Penelitian Kesehatan. Jakarta: Rineka Cipta.

Notoatmodjo, Soekidjo. (2007). Promosi Kesehatan dan Ilmu Perilaku. Cetakan I. Jakarta : PT. Rineka Cipta.

Nursalam. (2008). Konsep dan Penerapan Metodologi Penelitian Ilmu Keperawatan, Edisi 2. Jakarta: Salemba Medika.

Papalia, dkk. (2009). Perkembangan Manusia. Jakarta: Salemba Humanika.

Piaget. (2004). Ciri Perkembangan Sosial Anak. www.psikologizone.com.

Rini, Jacinta F. (2004). Wanita Bekerja. www.epsikologi.com.

Snowman dan patmoenodewo. (2004). Ciri Anak Prasekolah. .

Sunarto dan Hartono. (2004). Hubungan Sosial. www.sunartohartono. org/agents2.htm.

Soetjiningsih. (2004). Tumbuh Kembang Anak. Jakarta: EGC.

Whaly dan Wong. (2004). Anak Prasekolah. www.library.upnvj.ac.id/bab1.pdf.

Yusuf, Syamsul. (2007). Psikologi Perkembangan Anak dan Remaja. Bandung: Remaja Rosdakarya. 